\title{
Presence of plastic particles in waterbirds faeces collected in Spanish lakes ${ }^{\text {in }}$
}

\author{
J.A. Gil-Delgado ${ }^{\text {a }}$, D. Guijarro ${ }^{\text {a }}$, R.U. Gosalvez ${ }^{\text {b }}$, G.M. López-Iborra ${ }^{\text {c }}$, A. Ponz ${ }^{\text {d, }}$, A. Velasco ${ }^{\text {e }}$ \\ a ICBiBE, Universidad de Valencia, Polígono La Coma, s/n, 46980 Paterna, Valencia, Spain \\ b Departamento de Geografía y Ordenación del Territorio, Universidad de Castilla La Mancha, 13071 Ciudad Real, Spain \\ c Departamento de Ecología - IMEM Ramon Margalef, Universidad de Alicante, Aptdo. 99, 03080 Alicante, Spain \\ d Departamento de Didáctica de las Ciencias Experimentales, Facultad de Ciencias Sociales y Humanas, Universidad de Zaragoza, C/Ciudad Escolar, s/n, 44003 Teruel, Spain

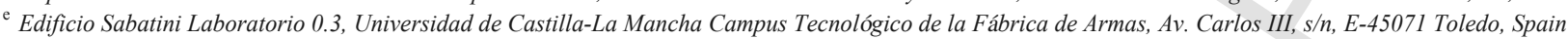

\section{A R T I C L E IN F O}

\section{Article history:}

Received 16 May 2016

Received in revised form 15 September 2016

Accepted 16 September 2016

Available online xxx

\section{Keywords:}

Plastic pollution

Continental lakes

Faeces

Waterbird species

\section{A B S T R A C T}

Plastic intake by marine vertebrates has been widely reported, but information about its presence in continental waterfowl is scarce. Here we analyzed faeces of waterbirds species (European coot, Fulica atra, mallard, Anas platyrhynchos and shelduck, Tadorna tadorna) for plastic debris in five wetlands in Central Spain. We collected 89 faeces of Shelduck distributed in four lakes, $43.8 \%$ of them presented plastic remnants. Sixty percent of 10 faeces of European coot and $45 \%$ of 40 faeces of mallard contained plastic debris. Plastic debris found was of two types, threads and fragments, and were identified as remnants of plastic objects used in agricultural fields surrounding the lakes. Differences in prevalence of plastic in faeces, number of plastic pieces per excrement and size of the plastic pieces were not statistically significant between waterfowl species. Thus, our results suggest that plastic may also be frequently ingested by waterfowl in continental waters, at least in our study area. Future studies should address this potential problem for waterbird conservation in other wetlands to evaluate the real impact of this pollutant on waterbirds living in inland water.

The faeces of three waterfowl species collected in inland lakes of Spain presented high prevalence of plastics, which have the potential of being a problem for birds. Stricter regulations for eliminating used agricultural plastics should be developed and applied.

(C) 2016 Published by Elsevier Ltd.

\section{Introduction}

Plastic pollution is a major emerging environmental problem (UNEP, 2011), whose effect has been studied mainly in marine environments (Derraik, 2002; Tourinho et al., 2010; Andrady, 2011; Ivar do Sul and Costa, 2014). Global plastic production has increased rapidly since mass production began in the $1950 \mathrm{~s}$ and currently exceeds 311 million tons per year (PlasticsEurope, 2015). An estimated $10 \%$ of this plastic ends up in oceans (Thompson, 2007). Eriksen et al. (2014) estimate a minimum of 5.25 trillion plastic particles, weighing 268,940 tons, to be floating in the world's oceans. Hundreds of species have been affected, including marine mammals (Madeira Di Benedito and Arruda Ramos, 2014), seabirds (Brandăo et al., 2011; Provencher et al., 2014), sea turtles (Bugoni et al., 2001; Tomás et al., 2002; Schuyler et al., 2013), fish (Boerger et al., 2010; Carson, 2013), benthic biota and plankton (Laist, 1987; Cole et al., 2011).

In the last few years, many studies have shown how this problem affects birds (Rohstein, 1973; Watanuki, 1985; Brandăo et al., 2011;

\footnotetext{
t This paper has been recommended for acceptance by Eddy Y. Zeng.

* Corresponding author.

Email addresses: gild@uv.es (J.A. Gil-Delgado); rafaelu.gosalvez@uclm.es (R.U. Gosalvez); german.lopez@ua.es (G.M. López-Iborra); adrian.ponz@ unizar.es (A. Ponz); angel.vgarcia@uclm.es (A. Velasco)
}

van Franeker et al., 2011; Bond and Lavers, 2013; Provencher et al., 2014; Gall and Thompson, 2015). Plastic debris has been found to be ingested in more than half the world's 300 seabird species (Vlietstra and Parga, 2002; Moore, 2008; Gall and Thompson, 2015). Spear et al. (1995) reported a negative relationship between plastic ingestion and physical condition in seabirds. Rochman et al. (2016) in a recent review of the evidence of the ecological consequences of marine debris found that most $(89 \%)$ of the demonstrated impacts were at suborganismal level of organization and were due to plastic debris. They conclude that, despite the deficiencies detected in some studies, there is sufficient evidence to begin to mitigate the plastic effects to avoid future risks. The potential effects of plastic consumption on seabirds include: internal and external wounds, blocked digestive tract, impaired feeding capacity, reduced reproductive capacity, and poisoning from absorbed toxic compounds (Gregory, 2009). Plastic debris can have deleterious effects on seabirds' health (Provencher et al., 2010). Seabird populations stressed by changing environmental conditions and reduced prey abundances may be more vulnerable to the negative impacts of plastics (Tanaka et al., 2010). Several researchers have even show seabirds to be biomonitors of plastic pollution (Ryan, 2008).

Information about the incidence of remains of plastics in the stomach of waterfowl and other species living in wetlands is apparently lacking (Provencher et al., 2015; Wagner et al., 2014; but see English et al., 2015), despite plastic debris being also present in some wetlands. Microplastic and coal ash have been observed in the Lau- 
rentian Great Lakes of the United States, and in Lake Hovsgol of Mongolia (Eriksen et al., 2013; Free et al., 2014). Gasperi et al. (2014) report that 27 tons of floating plastic debris are intercepted annually in the River Seine, which correspond to $2.3 \mathrm{~g}$ per Parisian inhabitant/ year. Such data could serve to provide a preliminary evaluation of floating plastic inputs conveyed by rivers.

As data on the effect of plastic debris on waterfowl are lacking, the aim of this paper is to publicise the first evidence of plastic ingestion by the shelduck Tadorna tadorna, categorised as near to threatened among Spanish bird species (Robledano, 2004), mallard (Anas plathyrhynchos) and European coot (Fulica atra).

\section{Methods}

We collected faeces from wetlands spread through the provinces of Cuenca (Manjavacas: $39^{\circ} 25^{\prime} \mathrm{N}, 2^{\circ} 51^{\prime} \mathrm{W}$; Dehesilla: $39^{\circ} 26^{\prime} \mathrm{N}, 2^{\circ}$ $50^{\prime} \mathrm{W}$ ), Ciudad Real (Alcahozo: $39^{\circ} 23^{\prime} \mathrm{N}, 2^{\circ} 52^{\prime} \mathrm{W}$; Camino de Villafranca: $39^{\circ} 25^{\prime} \mathrm{N}, 3^{\circ} 20^{\prime} \mathrm{W}$ ) and Toledo (Grande de Villafranca: $39^{\circ}$ $27^{\prime} \mathrm{N}, 3^{\circ} 20^{\prime} \mathrm{W}$; Mermejuela: $39^{\circ} 32^{\prime} \mathrm{N}, 3^{\circ} 8^{\prime} \mathrm{W}$ ), which cover most of La Mancha Humeda Biosphere Reserve (Fig. 1). More information about the study area can be found in Peinado and Gosálvez (2007).

We collected 89 fresh Shelduck faeces between December 2013 and April 2015 in four lakes: Alcahozo (1), Dehesilla (10), Mermejuela (11), and Manjavacas (67). Forty fresh mallard faeces were collected in October 2013 and April 2014 in Manjavacas and 10 fresh faeces of European coot in March 2014 in Grande de Villafranca Lake. To collect faeces we search for monospecific flocks resting in particular sectors of the shore or islands that presented bare soil and were frequented by these species. We waited $30-45 \mathrm{~min}$ and then approached the flock, which left the resting place. We collected a sam- ple of fresh faeces scattered through the area occupied by the flock to minimize the probability of collecting several faeces from the same individual. Size of the flocks sampled ranged between 6 (Shelduck in Mermejuela lake) to 1308 (Mallard). We carefully removed the faeces from the ground, with a spatula avoiding including in the sample ground particles.

Collected faeces were placed in paper bags, dried at room temperature, weighted and then frozen. We disaggregated each faeces in water, using tweezers and a mounted needle, and they were analyzed by mean a binocular magnifying glass. Plastic remains were assigned to the categories described by van Franeker et al. (2011) and their colour was also registered. Samples of abandoned plastic on cereal cultures and vineyard land were obtained to identify the plastic remains occurring in the faeces. Prevalence was computed as the proportion of faeces analyzed that contained plastics. We compared the prevalence of plastic in faeces between lakes (only Shelduck data) and among species using Generalized Linear Models (GLM) with binomial error, in which the dependent variable was the presence or absence of plastics in each faeces. We analyzed if the number of plastic pieces per faeces containing at least one plastic item varied between species using GLM with Poisson error. In these models the number of plastic pieces in each excrement was the dependent variable and the weight of the excrement was included as covariate to take into account the different sizes of the faeces of the species studied. We compared between species the size of the plastic pieces using Linear Mixed Models, to take into account that several plastic pieces are usually found in each faeces. In these models the length of each plastic fragment or thread was the dependent variable, the species was a fixed effect and the faeces was included as a random effect. All statistical analyses were performed using R (R Core Team., 2014). We used the "lme" function of the R library "nlme" (Pinheiro et al., 2014) to fit the mixed models. We used the function "glht" in the

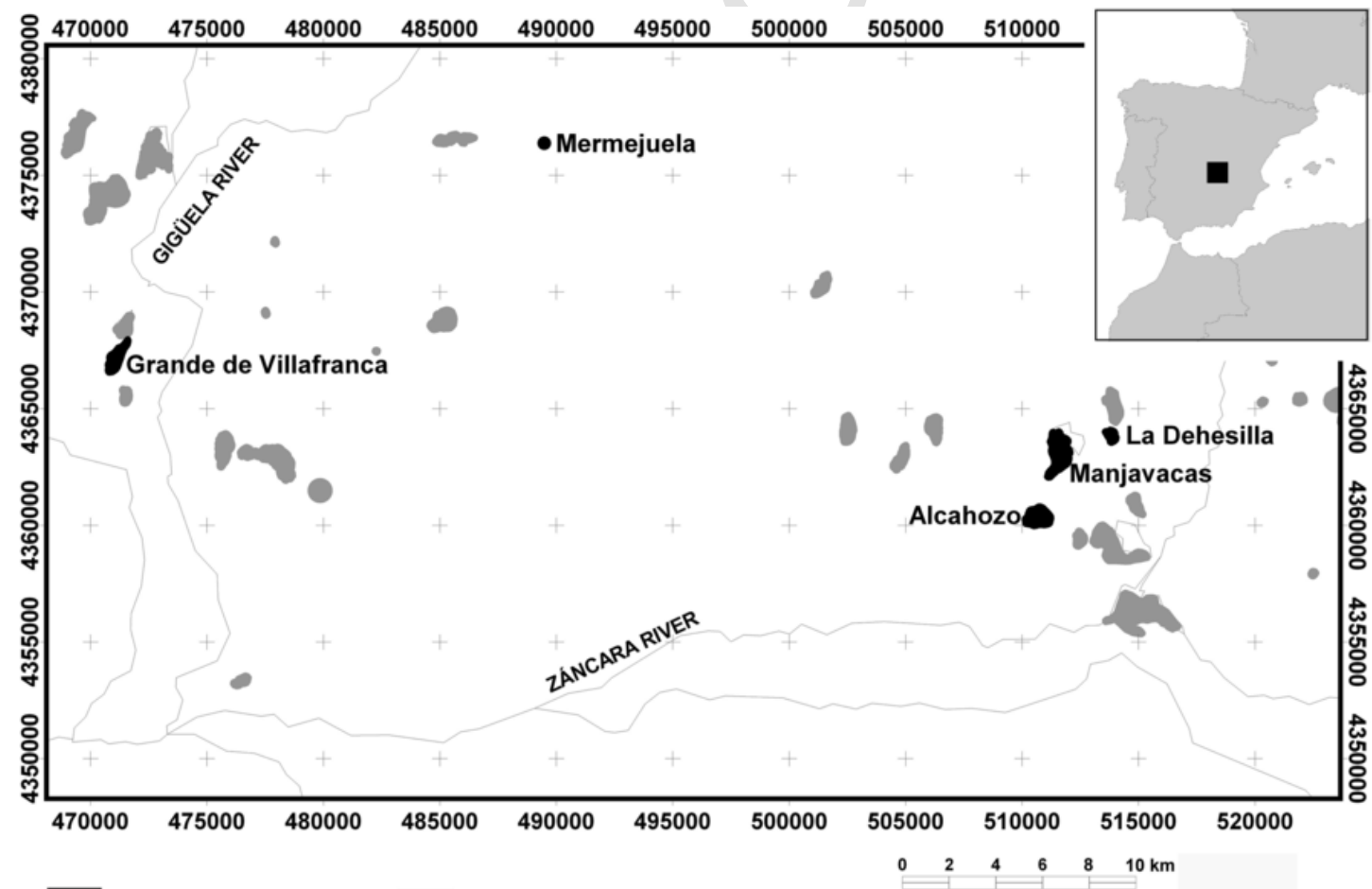

Selected shallow lake Shallow lake River

UTM Projection and Grid Zone 30. ETRS89 Datum.

Fig. 1. Location of the studied lakes (black) in Central Spain. 
package "multcomp" (Hothorn et al., 2008) to compare levels of the factors (species or lakes) when they were significant.

\section{Results}

All plastic remains found in faeces belong to the category of user plastics (non-industrial remains of plastic objects) of two types: fragments and threads (Table 1). They were identified as small pieces of the plastics used in crops to protect seedlings and portions of threads and thin strands. Threads found in the three species were mostly black (Shelduck: 76.6\%; Mallard: 71.9\%; Coot: $70.6 \%$ ) while $20.2 \%$ were red or blue in the samples of Shelduck and Mallard and $17.6 \%$ in Coot samples. The number of plastic fragments found in faeces is smaller (Table 1) and composed mainly of blue and red fragments in the Shelduck $(70.6 \%)$ and blue and white fragments $(100 \%)$ in the Mallard.

In Shelduck, $43.8 \%$ of the 89 faeces collected included plastic particles, mainly thread, but also plastic as small fragments. Faeces with plastic were collected in all the lakes, except Alcahozo (Table 1), but only one sample was collected in this lake. Comparison of prevalence among the other 3 lakes do not show significant differences in any plastic type (Deviance test, Fragments: $\chi^{2}=1.76, \mathrm{p}=0.41$; Threads: $\chi^{2}=0.12, p=0.94$; All types: $\chi^{2}=0.47, p=0.79$, df $=2$ ). However, plastic could have been ingested in any wetland because Shelduck movements were observed among some study lakes (Alcahozo, Dehesilla, Manjavacas). Sixty percent of 10 faeces of European coot and $45 \%$ of 40 faeces of mallard also contained plastic debris. We compared the prevalence of plastic among the three species and no significant differences were obtained (Deviance test, Fragments: $\chi^{2}=2.87$, $\mathrm{p}=0.24$; Threads: $\chi^{2}=1.32, \mathrm{p}=0.52$; All types: $\chi^{2}=0.90, \mathrm{p}=0.64$, $\mathrm{df}=2)$.

The GLM for the number of threads per faeces showed a significant effect of excrement weight (Deviance test: $\chi^{2}=29.54, p<0.001$, $\mathrm{df}=1)$, species $\left(\chi^{2}=19.94, \mathrm{p}<0.001, \mathrm{df}=2\right)$ and their interaction $\left(\chi^{2}=13.83, \mathrm{p}<0.001, \mathrm{df}=2\right)$. However, the multiple comparison among species did not detect differences between any of them $(p>0.3$ in all comparisons). None of the Coot faeces contained plastic fragments and the number of faeces of Shelduck and Mallard with this type of debris was too low to make sound comparisons. The size of the threads found in Shelduck faeces did not differ between lakes according to the mixed effects model $\left(\mathrm{F}_{2,35}=2.46, \mathrm{p}=0.100\right)$. When species are compared the size of threads found in their excrements is quite similar $\left(\mathrm{F}_{2,58}=1.14, \mathrm{p}=0.328\right)$. The mean size of plastic fragments in Shelduck and Mallard faeces was also very similar $\left(F_{1,13}=0.05\right.$, $\mathrm{p}=0.834)$.

\section{Discussion}

Our results have shown that the prevalence of plastic remains were high in faeces of three species of waterbirds. The types, colours and sizes of the plastic debris found in the three species studied were very similar so they have been likely exposed to the same type of plastic pollutants. For years the wetlands in our study area were used as dumps and may have accumulated different plastic types. Besides, most of these wetlands are located in endorheic watersheds in agricultural landscapes that probably tend to accumulate plastic transported by water or wind. The Shelduck diet is composed mainly of small invertebrates, primarily the mudsnail Hydrobia ulvae (Anders et al., 2009) usually taken in water. However, the fact that plants and other invertebrates typical of dry habitats were also present in the diet indicates that shelduck in our study area also exploit food resources in drier habitats in the edge of lagoons (Viain et al., 2011). Shelducks feed by moving their bills by a scything action, mainly in the top $2 \mathrm{~cm}$ of the muddy surface (Viain et al., 2011). Thus it is possible that their feeding method makes them particularly vulnerable to ingesting plastic. Microplastics, distributed by prevailing winds, tend to accumulate on lake shores (Free et al., 2014), thus the species that sieve the mud on the shore such as the shelduck and the mallard could be more prone to eating microplastic. However, similar prevalence of plastic in faeces was also found in the same areas in the European coot. That species feeds mainly in water but also feeds on land grazing near the shore, and could confound plastic debris with seeds or vegetal material. Thus, the three species share a common trait: they often use areas around lagoons, such as pasturelands, as feeding grounds, areas that may be prone to accumulate plastics.

Despite the large, growing literature on microplastic pollution in oceans, very little information on this subject is available for freshwater systems (Free et al., 2014). In rivers and lakes, most plastic items probably originate from voluntary or involuntary dumping, urban discharges, and surface runoff by water and wind (Eriksen et al., 2013; Gasperi et al., 2004; Free et al., 2014). The La Mancha Húmeda wetlands are surrounded by an agricultural landscape, which includes crops where plastics are often used in the form of protecting films or cords, which are a potential source of plastic debris. Thus, these wetlands could be particularly exposed to plastic pollution, which could be one reason to explain the high prevalence of plastic in the inland populations of the waterbirds studied. Previous reports showing the presence of plastics in the guts of freshwater waterbirds are scarce and among the species analyzed the highest plastic prevalence has been found in seabirds (Provencher et al., 2015). However, English et al. (2015) have discovered a high prevalence of plastic in

Table 1

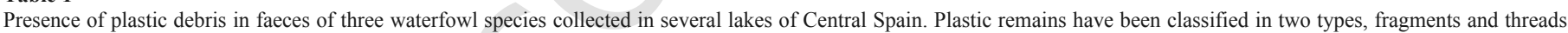

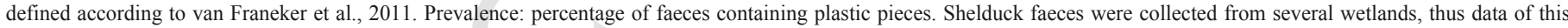

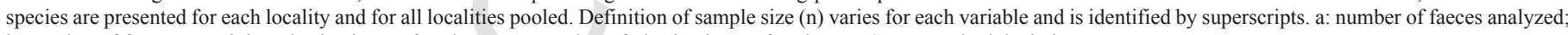
b: number of faeces containing plastic pieces of each type; $\mathrm{c}$ : number of plastic pieces of each type. SD = standard deviation.

\begin{tabular}{|c|c|c|c|c|c|c|c|c|c|c|c|c|c|c|c|c|c|c|c|c|}
\hline \multirow[t]{3}{*}{ Species } & \multirow[t]{3}{*}{ Lake } & \multicolumn{4}{|l|}{ Prevalence } & \multicolumn{8}{|c|}{ Number of plastic pieces per excrement with plastic } & \multicolumn{7}{|c|}{ Size of the plastic pieces (mm) } \\
\hline & & \multirow[b]{2}{*}{ Fragments } & \multirow[b]{2}{*}{ Thread } & \multirow[b]{2}{*}{ Total } & \multirow[b]{2}{*}{$\mathrm{n}^{\mathrm{a}}$} & \multicolumn{2}{|c|}{ Fragments } & \multirow[b]{2}{*}{ Range } & \multirow[b]{2}{*}{$\mathrm{n}^{\mathrm{b}}$} & \multicolumn{2}{|c|}{ Thread } & \multirow[b]{2}{*}{ Range } & \multirow[b]{2}{*}{$n^{b}$} & \multicolumn{2}{|c|}{ Fragments } & \multirow[b]{2}{*}{ Range } & \multirow[b]{2}{*}{$\mathrm{n}^{\mathrm{c}}$} & \multicolumn{2}{|c|}{ Thread } & \multirow[b]{2}{*}{ Range } \\
\hline & & & & & & Mean & SD & & & Mean & SD & & & Mean & SD & & & Mean & SD & \\
\hline \multirow[t]{5}{*}{ Shelduck } & Alcahozo & & & & 1 & & & & & & & & & & & & & & & \\
\hline & Dehesilla & 0.00 & 40.00 & 40.00 & 10 & & & & & 8.75 & 10.24 & $2-24$ & 4 & & & & & 1.64 & 0.91 & $0.5-4$ \\
\hline & Manjavacas & 14.93 & 44.78 & 46.27 & 67 & 1.40 & 0.70 & $1-3$ & 10 & 6.03 & 5.42 & $1-27$ & 30 & 1.29 & 0.54 & $0.5-2$ & 14 & 2.13 & 1.40 & $0.5-12$ \\
\hline & Mermejuela & 9.09 & 36.36 & 36.36 & 11 & 3.00 & & & 1 & 16.50 & 17.37 & $1-33$ & 4 & 2.33 & 1.44 & $1.5-4$ & 3 & 2.43 & 1.81 & $0.5-9$ \\
\hline & Total & 12.36 & 42.70 & 43.82 & 89 & 1.55 & 0.82 & $1-3$ & 11 & 7.42 & 8.17 & $1-33$ & 38 & 1.47 & 0.82 & $0.5-4$ & 17 & 2.14 & 1.47 & $0.5-12$ \\
\hline Mallard & Manjavacas & 10.00 & 42.50 & 45.00 & 40 & 1.00 & 0 & & 4 & 6.71 & 5.68 & $1-18$ & 17 & 1.38 & 0.48 & $1-2$ & 4 & 1.84 & 1.42 & $0.5-7.5$ \\
\hline Coot & Villacañas & 0.00 & 60.00 & 60.00 & 10 & & & & & 2.83 & 2.14 & $1-6$ & 6 & & & & & 2.03 & 1.24 & $0.5-4.5$ \\
\hline
\end{tabular}


some waterfowl species, including the mallard that presented plastic in $46.1 \%$ of the individuals analyzed, and therefore clearly showed that bird species using freshwater environments are also exposed to ingest plastic debris. Since the use of plastic in modern agriculture is widely distributed in the world this could be an overlooked emerging problem deserving further attention in other areas where wetlands are located in the middle of wide agricultural fields.

Presence of plastic-derived chemicals in biological tissues of marine birds can be explained by plastic ingestion and subsequent assimilation in the digestive system (Tanaka et al., 2013). Ingestion of marine debris, including plastic, can have lethal and sublethal effects on wildlife (Schuyler et al., 2013). Similar deleterious effects could be happening in freshwater birds, but knowledge about the biological effects of microplastic in freshwater species is very limited (Wagner et al., 2014).

We have shown a high prevalence of plastics in faeces of waterbirds in continental wetlands. Although faeces analysis is an indirect way of detecting the ingestion of plastics, and unknown factors may influence the processing of this contaminant through the bird gut and then its appearance in faeces, it may be an easy way to detect this problem under some conditions, without capturing or killing birds. If faeces are collected in resting areas of monospecific flocks and along several days or months we may be sure that they do not represent a reduced sample of few individuals. Therefore, given the shortage of data about the extent of plastic ingestion by freshwater birds, faeces analysis may provide an accessible method for starting to evaluate this problem. The results we have presented here advice for more detailed studies of plastic ingestion by inland waterbirds and support that stricter regulations for eliminating used agricultural plastics from these landscapes should be developed and applied.

\section{Acknowledgements}

This work was performed within the framework of Project ECOLAKE "Ecological patterns in endorheic lakes: the keys to their conservation, CGL2012-38909", funded by the Spanish Ministry of Economy and Competitiveness, and by the European Union through the European Fund for Regional Development (FEDER) "One way to make Europe". We also thank Helen Warburton for helping with the English. J. Viñuela and E. Garcia provided helpful comments. We wish to thank also the three anonymous reviewers that contributed to improve the original manuscript. The authors have been sorted by alphabetical order.

\section{References}

Anders, N.R., Churchyard, T., Hiddink, J.G., 2009. Predation of the Shelduck Tadorna tadorna on the mud snail Hydrobia ulvae. Aquat. Ecol. 43, 1193-1199.

Andrady, A.L., 2011. Microplastics in the marine environment. Mar. Pollut. Bul. 62, 1596-1605

Boerger, C.M., Lattin, G.L., Moore, S.L., Moore, C.J., 2010. Plastic ingestion by planktivorous fishes in the North Pacific Central Gyre. Mar. Pollut. Bul. 60, 2275-2278.

Brandăo, M.L., Braga, K.M., Luque, J.L., 2011. Marine debris ingestion by magellanic penguins Spheniscus magellanicus (Aves: sphenisciformes), from the Brazilian coast zone. Mar. Pollut. Bul. 62, 2246-2249.

Bond, A.L., Lavers, J.L., 2013. Efectiveness of emetics to study plastic ingestion by Leach's storm-petrels (Oceanodroma leucorhoa). Mar. Pollut. Bul. 70, 171-175.

Bugoni, L., Krause, L., Petri, M.V., 2001. Marine debris and human impacts on sea turtles in Southern Brazil. Mar. Pollut. Bul. 42, 1330-1334.

Carson, H.S., 2013. The incidence of plastic ingestion by fishes: from the prey's perspective. Mar. Pollut. Bul. 74, 170-174.

Cole, M., Lindeque, P., Halsband, C., Galloway, T.S., 2011. Microplastics as contaminants in the marine environment: a review. Mar. Pollut. Bul. 62, 2588-2597.

Derraik, J.G.B., 2002. The pollution in marine environment by plastic debris: a review. Mar. Pollut. Bul. 44, 842-852.
English, M.D., Robertson, G.J., Avery-Gomm, S., Pine-Hay, D., Roul, S.R., Ryan, P.C., Wilhem, S.I., Mallory, M.L., 2015. Plastic and metal ingestion in three species of coastal waterfowl wintering in Atlantic Canada. Mar. Pollut. Bul. 98, 349-353.

Eriksen, M., Lebreton, L.C.M., Carson, H.S., Thiel, M., Moore, C.J., Borrero, J.C., Galgani, F., Ryan, P.G., Reisser, J., 2014. Plastic pollution in the world's oceans: more than 5 trillion plastic pieces weighing over 250,000 Tons afloat at sea. PLoS One 9 (12), e111913. http://dx.doi.org/10.1371/journal.pone.0111913.

Eriksen, M., Mason, S., Wilson, S., Box, C., Zellers, A., Edwards, W., Farley, H., Amato, S., 2013. Microplastic pollution in the surface waters of the Laurentian great lakes. Mar. Pollut. Bul. 77, 177-182.

Free, C.M., Jensen, O.P., Mason, S.A., Eriksen, M., Williamson, N.J., Boldgiv, B., 2014. High-levels of microplastic pollution in a large, remote, mountain lake. Mar. Pollut. Bul. 85, 156-163.

Gall, S.C., Thompson, R.C., 2015. The impact of debris in marine life. Mar. Pollut. Bul. 92, 170-179.

Gasperi, J., Dris, R., Bonin, T., Rocher, V., Tassin, B., 2014. Assessment of floating plastic debris in surface water along the Seine River. Environ. Pollut. 195, 163-166.

Gregory, M.R., 2009. Environmental implications of plastic debris in marine settings-entanglement, ingestion, smothering, hangers-on, hitch-hiking and alien invasions. Philos. Trans. R. Soc. Lond., B, Biol. Sci. 364, 2013-2025.

Hothorn, T., Bretz, F., Westfall, P., 2008. Simultaneous inference in general parametric models. Biom. J. 50, 346-363.

Ivar do Sul, J.A., Costa, M.E., 2014. The present and future of microplastic pollution in the marine environment. Environ. Pollut. 185, 352-364.

Laist, D.W., 1987. Overview of the biological effects of lost and discarded plastic debris in the marine environment. Mar. Pollut. Bul. 18, 319-326.

Madeira Di Benedito, A.P., Arruda Ramos, R.M., 2014. Marine debris ingestion by coastal dolphins: what drives differences between sympatric species?. Mar. Pollut. Bul. 83, 298-301.

Moore, C.J., 2008. Synthetic polymers in the marine environment: a rapidly increasing, long-term threat. Environ. Res. 108, 131-139.

Peinado, M., Gosálvez, R.U., 2007. II. El medio natural. 3. Las aguas. In: Pillet, F. (Ed.), Geografía de Castilla-La Mancha. Almud Ediciones de Castilla-La Mancha, Ciudad Real, pp. 67-84.

Pinheiro, J., Bates, D., DebRoy, S., Sarkar, D., R Core Team, 2014. nlme: Linear and Nonlinear Mixed Effects Models. R. package version 3. 1-117. $\overline{\mathrm{h} t t p}: / / \mathrm{CRAN}$ R-project.org/package $=$ nlme $>$.

PlasticsEurope, 2015. Plastics - the facts 2015: an analysis of European latest plastics production. Demand and Waste Data. Plastics Europe, Brussels.

Provencher, J.F., Gaston, A.J., Mallory, M.L., O'hara, P.D., Gilchrist, H.G., 2010. Ingested plastic in a diving seabird, the thick-billed murre (Uria lomvia), in the eastern Canada Artic. Mar. Pollut. Bul. 60, 1406-1411.

Provencher, J.F., Bond, A.L., Hedd, A., Montevecchi, W.A., Muzaffar, S.B., Courchesne, S.J., Gilchrist, H.G., Jamieson, S.E., Merkel, F.R., Falk, K., Durinck, J., Mallory, M.L., 2014. Prevalence of marine debris in marine birds from the North Atlantic. Mar. Pollut. Bul. 84, 411-417.

Provencher, J.F., Bond, A.L., Mallory, M.L., 2015. Marine birds and plastic debris in Canada: a national synthesis and a way forward. Environ. Rev. 23, 1-13.

$\mathrm{R}$ Core Team, 2014. R: a language and environment for statistical computing. R Foundation for Statistical Computing. Austria, Vienna. http://www.R-project.org/.

Robledano, F., 2004. Tarro blanco. In: Madroño, A., González, C., Atienza, J.C. (Eds.), Libro Rojo de las Aves de España. Organismo Autónomo Parques Nacionales. Ministerio de Medio Ambiente, Madrid, pp. 87-89.

Rochman, C.M., Browne, M.A., Underwood, A.J., Van Franeker, J.A., Thompson, R.C., Amaral- Zettler, L.A., 2016. The ecological impacts of marine debris: unraveling the demonstrate evidence from what is perceived. Ecology 97, 302-312.

Rohstein, S.L., 1973. Plastic particle pollution of the surface of Atlantic Ocean: evidence from a seabird. Condor 75, 344-345.

Ryan, P.G., 2008. Seabirds indicate changes in the composition of plastic litter in the Atlantic and south-western Indian Oceans. Mar. Pollut. Bul. 56, 1406-1409.

Schuyler, Q., Hardesty, B.D., Wilcox, C., Townsend, K., 2013. Global analysis of anthropogenic debris ingestion by sea turtles. Conserv. Biol. 28, 129-139.

Spear, L.B., Ainley, D.G., Ribic, C.A., 1995. Incidence of plastic in seabirds from the tropical Pacific, 1984-91: relation with distribution of species, sex, age, season, year and body weight. Mar. Environ. Res. 40, 123-146.

Tanaka, K., Takada, H., Yamashita, R., Mizukawa, K., Fukuwaka, M.A., Watanuki, Y., 2013. Accumulation of plastic-derived chemicals in tissues of seabirds ingesting marine plastics. Mar. Pollut. Bul. 69, 219-222.

Thompson, R.C., 2007. Plastic debris in the marine environment: consequences and solutions. In: Krause, J.C., von Nordheim, H., Bräger, S. (Eds.), Marine Nature Conservation in Europe 2006. Bundesamt für Naturschutz, Bonn, pp. 107-116.

Tomás, J., Guitart, R., Mateo, R., Raga, J.A., 2002. Marine debris ingestion in loggerhead sea turtles, Caretta caretta, from the Western Mediterranean. Mar. Pollut. Bul. 44, 211-216.

Tourinho, P.S., Ivar do Sul, J.A., Fillmann, G., 2010. Is marine debris ingestion still a problem for the coastal marine biota in Southern Brazil?. Mar. Pollut. Bul. 60, 396-401. 
UNEP, 2011. UNEP Year Book. 2011. Emerging Issues in Our Global Environment. United Nations Environment Programme, Nairobi.

van Franeker, J.A., Blaize, C., Danielsen, J., Fairclough, K., Gollan, J., Guse, N., Hansen, P.L., Heubeck, M., Jensen, J.K., Le Guillouj, G., Olsen, B., Olsen, K.O., Pedersen, J., Stienen, E.W.M., Turner, D.M., 2011. Monitoring plastic ingestion by the northern fulmar Fulmarus glacialis. Environ. Pollut. 159, 2609-2615.

Viain, A., Corre, F., Delaporte, P., Joyeux, E., Bocher, P., 2011. Numbers, diet and feeding methods of Common Shelduck Tadorna tadorna wintering in the estuarine bays of Aiguillon and Marennes-Oléron, western France. Wildfowl 61, 121-141.

Vlietstra, L.S., Parga, J.A., 2002. Long-term changes in the type, but not amount, of ingested plastic particles in short-tailed shearwaters in the southeastern Bering Sea. Mar. Pollut. Bul. 44, 945-955.
Wagner, M., Scherer, C., Alvarez-Muñoz, D., Brennholt, N., Bourrain, X., Buchinger, S., Fries, E., Grosbois, C., Klasmeier, J., Marti, T., Rodriguez-Mozaz, S., Urbatzka, K., Vethaak, A.D., Winther-Nielsen, M., Reifferscheld, G., 2014. Microplastics in freshwater ecosystems: what we know and what we need to know. Environ. Sci. Eur. 26, 12. http://dx.doi.org/10.1186/s12302-014-0012-7.

Watanuki, Y., 1985. Food of breeding Leach's storm-petrels (Oceanodroma leucorrhoa). Auk 102, 884-886. 